\title{
INTERACTING WITH INTERIORS: FUNCTIONALITY, COMFORT AND DECORATION IN LISBON AT THE TRANSITION OF 20th CENTURY
}

\author{
María Margarida Rendeiro* \\ Cristina Caramelo Gomes* \\ Lusíada University of Lisbon
}

\begin{abstract}
This paper aims to establish that space becomes a place whenever an individual uses it, interacts with the environment and with others. It also shows that the interiors are more than functional units and are key signifiers when determining the identity of the dweller. Research is oriented towards the period of transition from 19th to 20th centuries and uses architecture and literature as key research sources. A semiotic approach complements and provides an insight into the potential meaning of decoration and room allocation, in particular, as far as the determination of the public and private spheres are concerned. The Parisian model offered interesting recreations of the French trend adapted into a Portuguese environment, historically defined and ideologically planned. Layout

Key Words - Interiors Design, Semiotics, Literature, Domesticity, Space

\section{Resumo}

O presente artigo pretende demonstrar que o espaço se transforma em lugar sempre que o indivíduo o usa, interage com o ambiente, e com os outros. Procura igualmente mostrar que os interiores são mais do que meras unidades funcionais e que se assumem significantes essenciais para a definição da identidade do utilizador e particularmente do morador. A investigação é orientada para o período que corresponde à transição do século XIX para o seguinte e utiliza a arquitectura e a literatura como fontes primárias. Uma abordagem semiótica complementa e expande as potencialidades significativas da decoração e da organização de espaços e funcionalidades, particularmente no que diz respeito à separação das áreas pública e privada. O modelo parisiense oferece reinvenções interessantes da tendência francesa adaptada ao ambiente português, historicamente definido e ideologicamente planeado. A sua recriação ilustra frequentemente um cenário cosmopolita frequentemente incoerente com a sua apropriação pelos hábitos e costumes dos lisboetas.
\end{abstract}


Palavras Chave: Design de Interiores, Semiótica, Literatura, Domesticidade, Organização de Espaço

\section{Introduction}

Man is naturally social. Individuals need to interact with each other and this interaction is developed within spatial environment. It is widely accepted that space shapes characters and influences moods through physical configuration and ambiences. This bi-univocal relation makes individuals into users and space into place. By place, it is suggested that the process of appropriation plays a role in the making of the identity of a community during a period of time.

Space moulds the scenarios - "settings" - in which users behave and interact with each other in and with the environment. The concept of behavioural setting defined by Baker (1968) ${ }^{1}$ shows that the behaviour of users is influenced throughout stimulation or constrained by these scenarios and/or settings (physical and social environment). He established that places have synomorphy whenever the activities of users and their physical and social setting are correlated. The cornerstones of this correlation are privacy and community, as well as the ritual, display and surveillance factors. Particular spaces motivate users to act out social rituals; other spaces motivate the display of objects and individuals to society. Users depend on space to create places suitable to specific activities and to tell others what they mean. In the end, space shapes the settings that facilitate the acting out of various personae that users impersonate in their daily routines. "Whatever space and time mean, place and occasion mean more. For space in the image of man is place, and time in the image of man is occasion." (Van Eyck, 1962 apud Hertzberger, 2005: 1932). As Roland Barthes established in his Mythologies $(2013)^{3}$, most rituals in society orient the members of a community towards common and particular interpretations; in other words, they produce connotative readings. Defining a specific environment, decorating a room, choosing materials, fabrics and setting a table for teatime are signs in the mind of the members of the community because they are read connotatively as signifiers of social status. A china cup, a long dress or an apron can be read denotatively according to their usefulness (quenching someone's thirst, getting dressed or protecting a garment from getting dirty) but they are also signs of social status. Individuals interact by using verbal and non-verbal codes; as a result, their own position in society is established. This is the basis of a social myth.

This paper uses architecture and literature as semiotic signs that convey the social, economic and cultural mainstream. Interiors are reinterpreted by their users according to their conveniences, including their private and communal daily routine. Hence, interiors become semiotic signs that perpetuate and 
challenge social myths. Layouts are more than décor; they express a conceptual design of ambience and mood and convey a role in the hierarchical structure of society. Interaction between human and domestic environs encourages the making of a space into a venue, a house into a home; in other words, interaction enables appropriating a space, making it as an extension of the user's selfidentity.

The 19th century is characterized by a domesticity that emerged to respond to the expectations of individuals as far as comfort and social status were concerned. Not only did the Industrial Revolution stimulate technological development but it also encouraged the establishment of a new social class whose needs and expectations were satisfied through features and ambiences of interior scenarios, particularly those domestic. The importance assigned to domesticity conceptualized dimensions, layout, functionality and finishes of interiors in order to define the idea of comfort and social status of a family or a community. At the transition of the 20th century, Lisbon was not different. Some areas of the city were widely used as exterior scenarios to carry out social actions which varied depending on gender and social status. The family mansions were places that encouraged rituals for private and social purposes; the rest of the city was an unhealthy and insecure place, used as shelter by the peasants that migrated to the city to work at factories.

In spite of emulating foreign models, particularly the Parisian ones, the Portuguese urban society created its own language associated with functions and social status. The main hall was the hub from which the layout was structured. It was also the place whose function was fundamentally social; in other words, of the public sphere: hosts and guests sat and entertained to see and be seen. Outside this place, rooms were allocated according to their function and to the social status of dweller. The higher the social status, the more separate the public and private spheres. Visitors were welcomed in the lounge; men had their studios whereas ladies preferred the boudoir (with a place for dressing and another for receiving the intimae personages); each room filled in a particular function and, thus, rendered a specific mood of intimacy and become a sign of expression. Furnishings became more comfortable and suitable to the place: sofas were placed perpendicularly to the walls supported by small coffee tables. Chairs, like clothes, had skirts and curtains were withdrawn like skirts and dresses; the pattern of the wall paper was not too different from that of dresses. The idea of comfort prevailed when defining the layout of interiors and was similar to concerns with dressing.

The methodology of this analysis is structured into the following significant guidelines. On the one hand, and in the pursuit of examining the typology and interiors, it looks into two relevant examples of Portuguese architecture, built at the end of the 19th century: the mansion Silva Graça ${ }^{4}$ built by the architect Ventura Terra (1866-1919), in Lisbon, and the Vila Dias ${ }^{5}$, a vila operária, built in Marvila which was in the outskirts of Lisbon at that time. It reviews relevant literature produced on domesticity and on the evolution of the house concept. In addition, it uses specific examples of Portuguese literature 
published at the turn to the 20th century, in particular, Os Maias by Eça de Queirós (1845-1900) ${ }^{6}$ e Amanhã by Abel Botelho (1856-1917) ${ }^{7}$. These novels were published in 1888 and 1902. Both novelists used their novels as reflections of the prevailing values, prejudices and customs of the Portuguese society during that particular period. The relevance given to privacy and public area is highlighted. Finally, this paper explores Semiotics, in particular, the concepts of Connotation and Myth defined by Roland Barthes, with the purpose of establishing that, ultimately, the concept of home and fashion are intentionally and inevitably built upon the social nature of man in such a way that their function becomes an expression of social status.

\section{Lisbon at the Transition of the Century: 19th to 20th Century}

The construction of human identity is grounded upon the sense of belonging to a place. This is the requirement for belonging to a group that includes collective ideas of social, financial, cultural, or just thematic nature ${ }^{8}$.

At the transition from 19th to 20th century, Lisboners were not an exception. The features of one period were described in various forms of art, including fashion. An insight into literature shows the asymmetric experiences lived in various points of the city, from downtown to the periphery, from mansions to inhumane houses. At that time, Lisbon was a developing city, compared with the standards shown in other European capitals. The city was uncomfortable. It had unhealthy urban and housing environments. Water was supplied to houses through a poor system of water supply and sewage emerged as a central problem. Inhabitants threw dejects away shouting "água vai". 9 The working class communities particularly hit by this problem because individuals and families inhabited inhumane spaces.

The Industrial Revolution was an opportunity to change the structure of the city. The urban population was composed of individuals from different social backgrounds. The emergence of the proletariat and of the bourgeoisie was a reason for a significant expansion of the city. New and larger complexes were built and many were available to letting ${ }^{10}$. Downtown was the favourite place of Lisboners with a craving for catwalking along the Avenida da Liberdade and Chiado. Chiado was designed upon the Parisian model. Socially speaking, the boulevard was a sign whose significance was built upon female and male roles: women were expected to attend shops and churches whereas cafes, bars and theatres were potentially attended by men. Shopping and praying were rites expected to be carried out by women and men were given the role of public entertaining and ostensive socializing. This was true in urban centres and Lisbon was, therefore, no exception as far as putting this semiotic myth into practice. Barthes (2013) recognizes functional implications in the composition of the myth. At that time, Chiado was the venue where most cafes, bars, theatres became the privileged places for the discussion of intellectual and political ideas. These meetings were mostly attended by men involved in art, literature and science. 


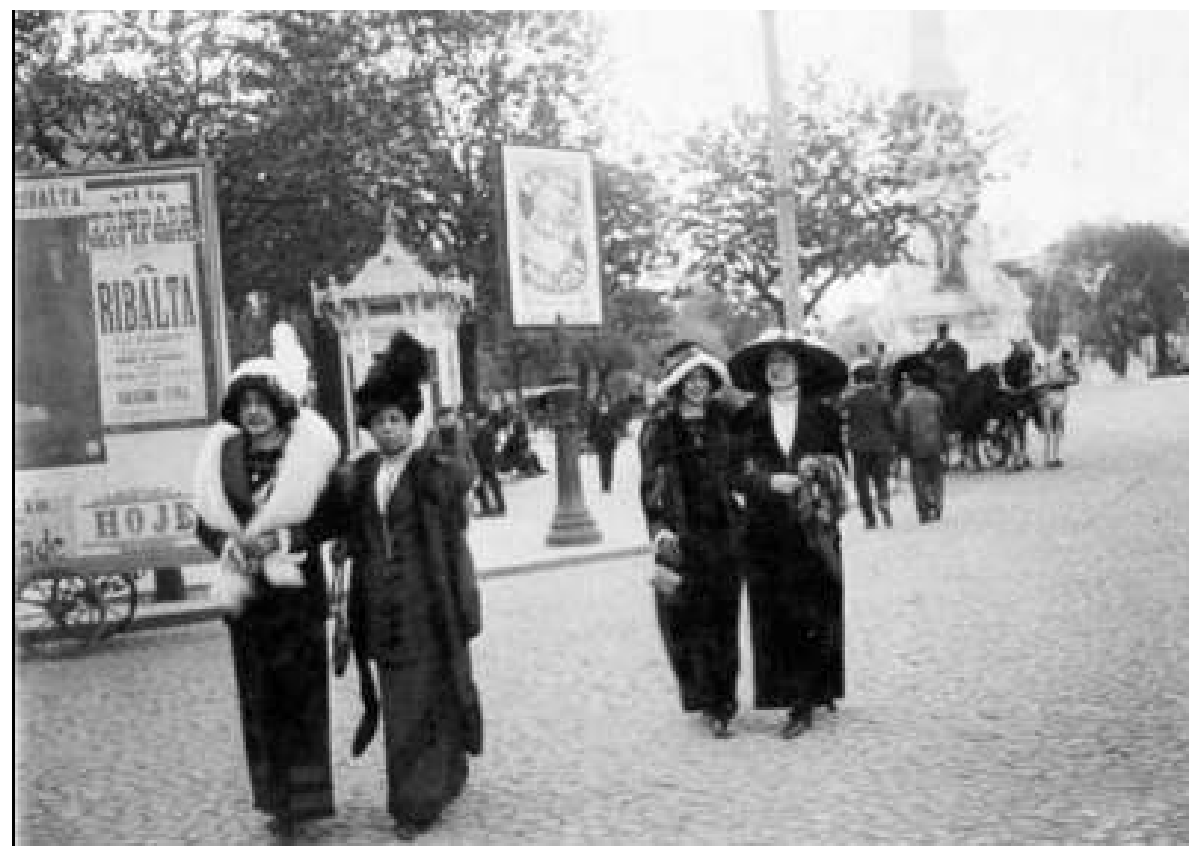

Fig. 1 - Av. Da Liberdade, $1912^{11}$

Rybczynski (1987) stated that technology brought some changes on domestic environment ${ }^{12}$. Gas and ventilation boosted the efficiency of mansions. Muthesius (2008) distinguished comfort from decor. Comfort takes convenience to further limits, such as technical developments to integrate physical and psychological qualities. The dimension of rooms, specialised functions, heating, light, door locks, carpets, and upholstered furniture and wall papers materialise physical quality whilst the experience of the space and sense of wellbeing illustrate the psychological quality.

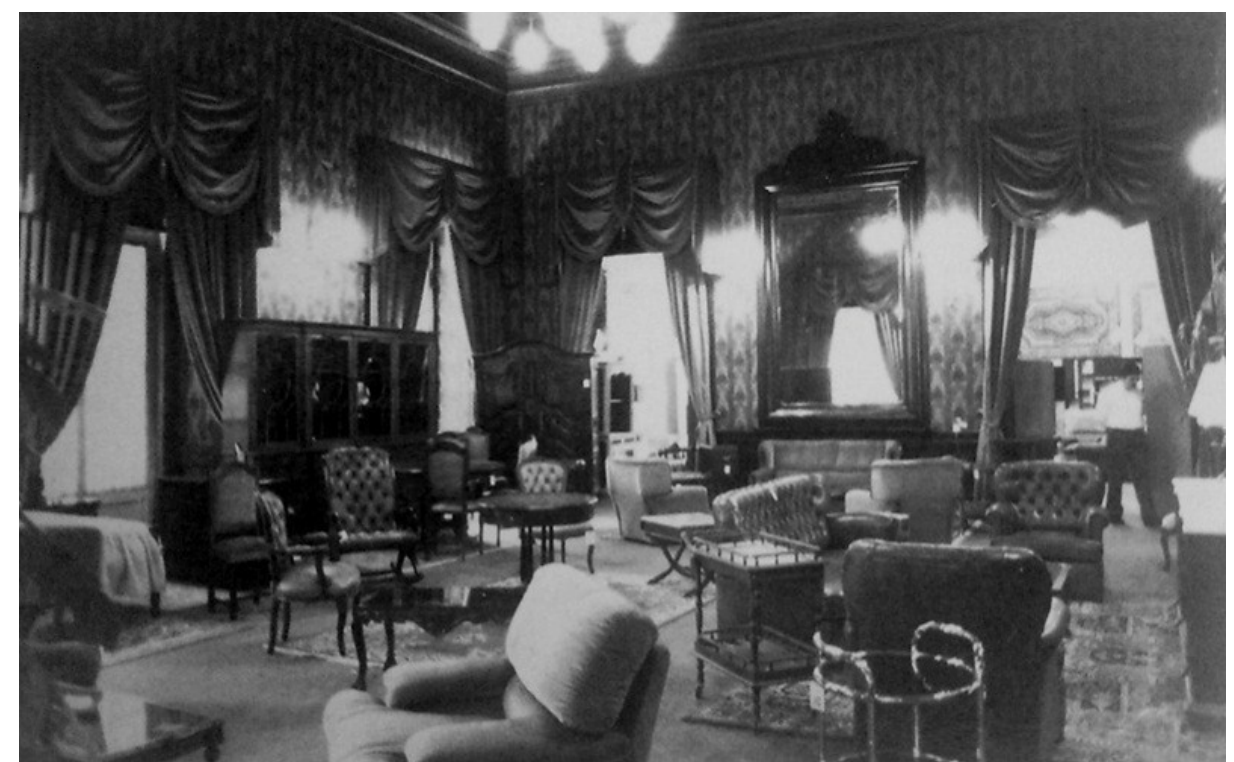

Fig. 2 - Armazens do Chiado, Hall of decor, which motto was "Bien faire et laisser dire",13. 
Decor conveyed social status. Muthesius (2008) claimed that the décor of interiors was a demonstration of wealth and social status ${ }^{14}$. Despite importing or adapting models and trends, the objective was to create different ambiences in order to comply with functions and expected social behaviours customised by functional and gender-based human performances. Houses became more efficient and interiors were decorated according to personal decisions. There was a difference between comfort and commodity: comfort was the passive usufruct of the house whereas commodity was the correct functioning of the house.

Peter Thornton (2001) considered that this century was the period of great domesticity ${ }^{15}$. Interiors conveyed their importance according to the ambience and mood that they could stimulate. Home was a place of intimacy with friends and family as well as a refugee from exterior world. The soaring number of specialised and functional rooms as boudoirs, drawing-rooms, smoking rooms, libraries and bedrooms motivated a new physical interiority, and it enabled solitary abandonment and private contemplation ${ }^{16}$. The way individuals understood their home conveyed personal status and was established by a particular style and social code. Interiors became home environments, personal style and economic possibilities created ambience and mood was created and differed according to individual or family affordability. In other words, home became much more than a shelter. Muthesius (2008) stated that ambience was shaped through little nest spots, like enclosures in the house; through deliberate light shadow jigsaw created by windows, apertures and curtains; and through chairs, sofas, stools, elegant bound books, vases for flowers, and other articles of sophistication, taste, and adornment ${ }^{17}$.

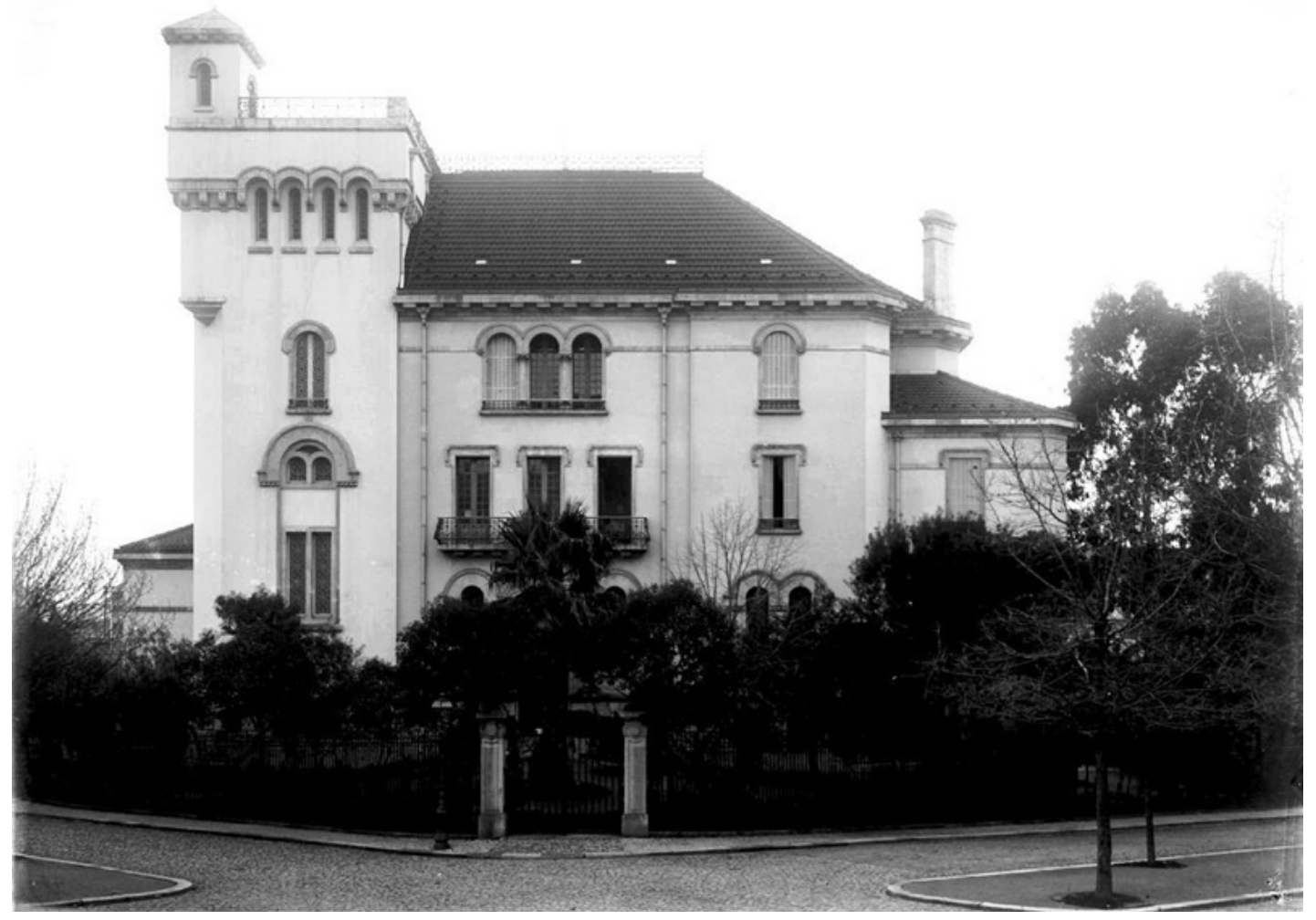

Fig. 3 - Mansion Silva Graça. Architectural design Ventura Terra, 1907. Exterior façade ${ }^{18 .}$ 
The typology of the dwelling environment pursued the inspiration of the historical period, place and the will of the owner of site ${ }^{19}$. Drafted typologies conveyed the idea of comfort and health, enhancing the living habitats and promoting the social image of their owners: examples worked as models to reproduce as the industrial revolution reproduced its objects. The Parisian housing inspired the Portuguese reality due to the geographical proximity and the intellectual development of Paris, the city where some of the Portuguese architects got their degree.

The number of symmetric dwelling paradigms boomed at the end of 19 th century and the beginning of 20th. Houses for industrial workers were unhealthy, uncomfortable, populated, inhumane environments, whereas the typical bourgeois dwelling was a one-family detached house and often one to let.

The one-family dwelling model included a vertically-oriented distribution of functions.

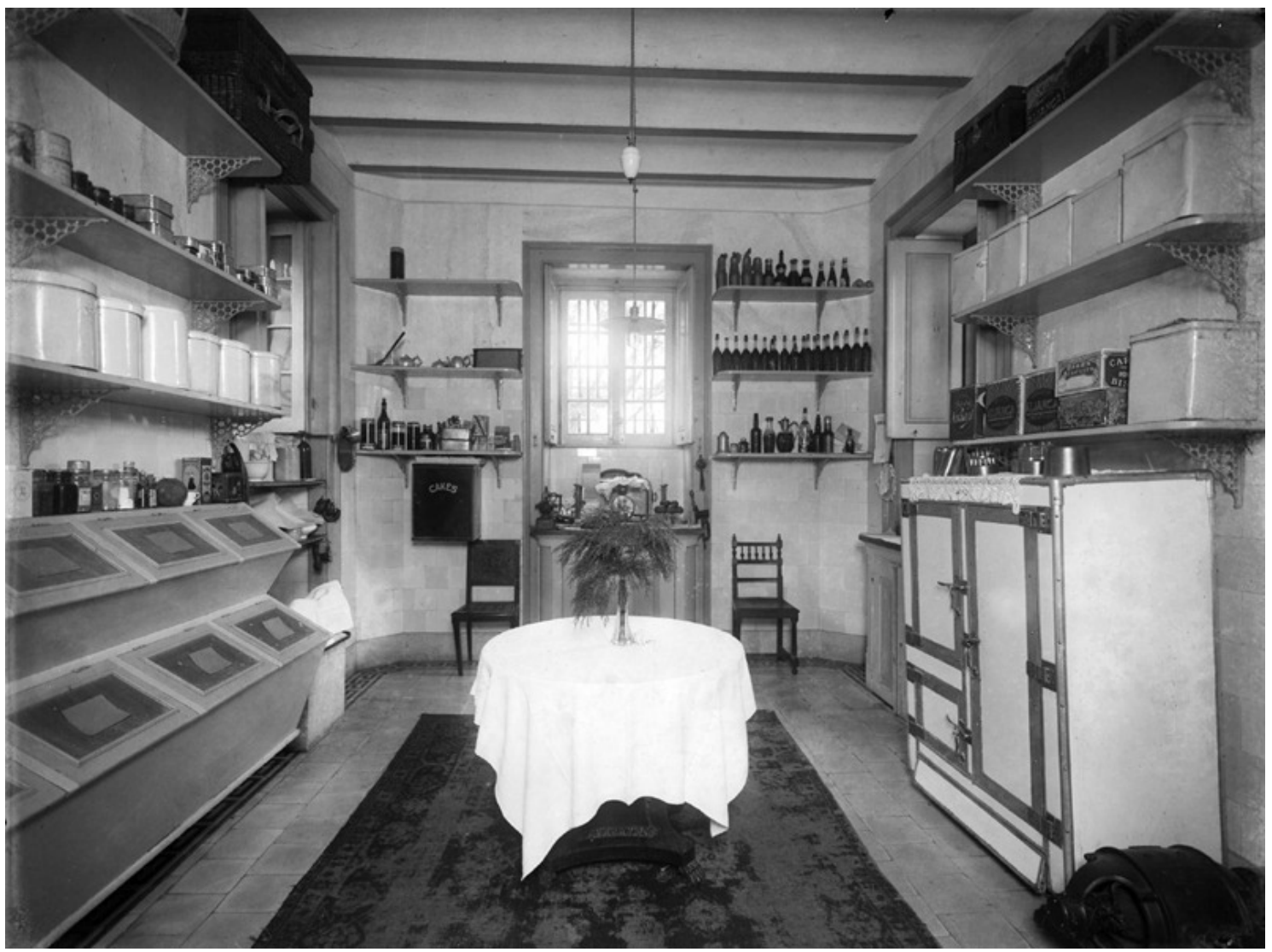

Fig. 4 - Mansion Silva Graça. Kitchen on the basement ${ }^{20}$

In the basement there were the kitchen and the rooms of the servants; the ground floor corresponded the public area with the living room, dining room and the study room; the upper floor was an area with a different function: rooms for servants; working area (preserving ancient traditions); an atelier for the past times of proprietors. At that time, having an atelier was a sign of luxury and a sign of belonging to an intellectual and/or artistic avant-garde cluster. 


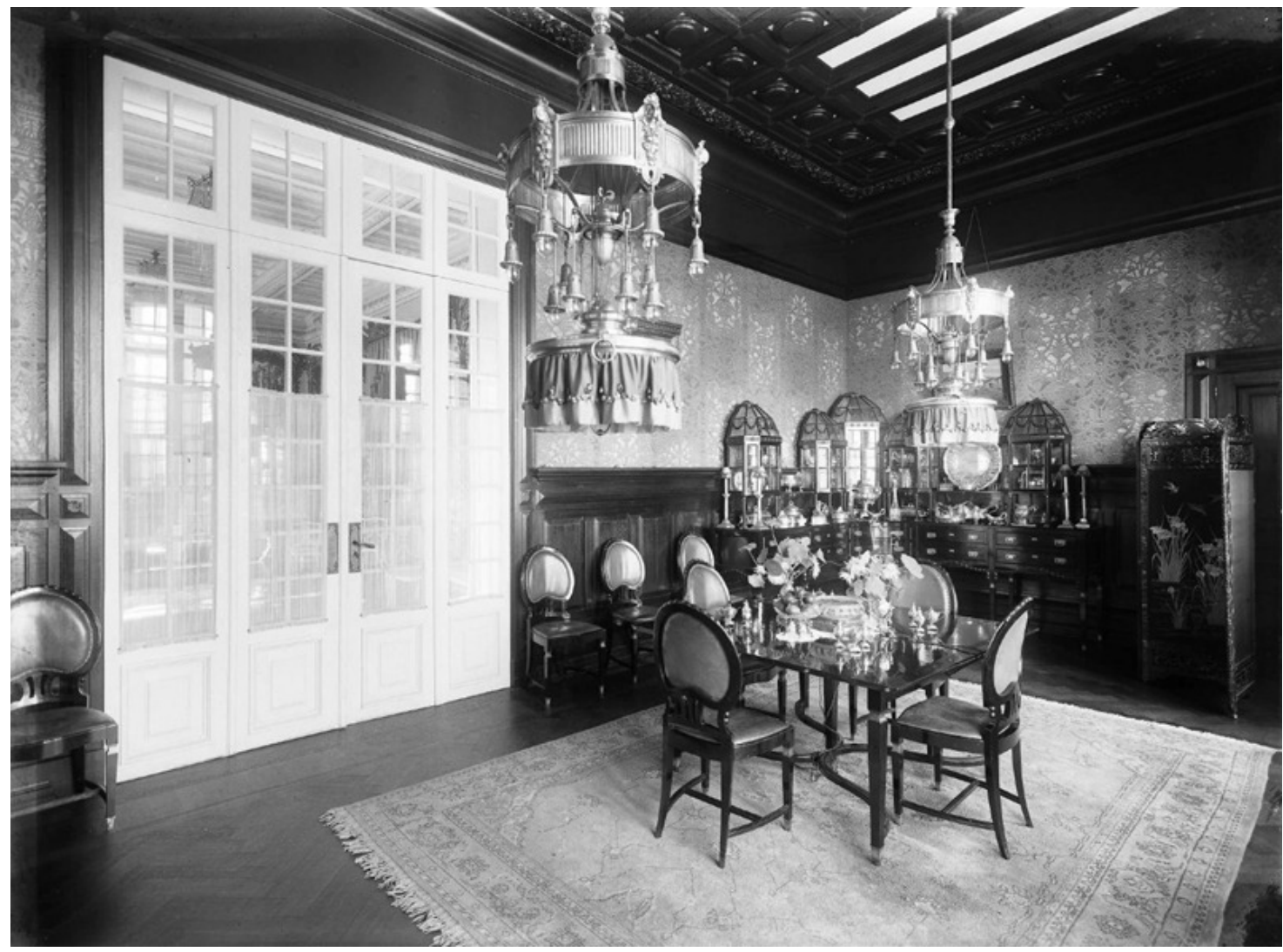

Fig. 5 - Mansion Silva Graça. Dining room ${ }^{21}$

The luxury house was similarly organized and separated servants from owners and the public area from private. The public area corresponded to the front façade, thus facing the main street; the private area faced the patio in the interior of the building. The area where the services were installed was contiguous to the private area, or in a symmetric element of the building. The space configuration of the houses established the importance of the social life of the owners, as the luxurious image of the façades and the public rooms showed the financial condition of the occupants. Corridors were planned to give access to particular areas and enhanced the sense of privacy. However, interdependence of the different areas was preserved in order to promote their flexibility or continue the old models. Ariès (1965) pointed out that, at the beginning of 20th century, the bourgeois society gave particular importance to the formality of family relations and to social relations ${ }^{22}$. The importance achieved by family interaction enhanced the sense of domesticity which implied the association of the dwelling typology layout with particular functions. The man of that time was appraised by others according to his profession, business and social relations. The study room was the place to work; where he entertained friends, clients and suppliers. Simão (2009) highlighted that this area could be fit for smoking; however in the most luxurious houses, the study room included a fumoir, a place for smoking, and could be complemented by a billiard table ${ }^{23}$. The study room was located near the main entrance and sometimes had an independent entrance to bar the invasion of the home. This detail was also implemented in the buildings to let. The desire 
of living healthy environments led to the inclusion of the WC in the house. Rybczynski (1987) added that the WC was considered luxury/fashionable area/equipment and, consequently, its function was relegated to second ${ }^{24}$.

The concept of 'Vila' emerged at the end of the 19th century. It merged the concepts of living and working nearby and that of "Pátio". The 'Pátios' consisted of families living in community in a small area where neighbourhood relations were essential. A rural environment was recreated. In other words, the concept of community similar to that prevailing in rural areas was reinvented in an urban context. This is particularly relevant because the core significance of rurality includes basic concepts, such as belonging to a community and sharing an identity. In this context, the concept of privacy was relegated to second. The 'Vilas' were small quarters, closed to the public street and facing an interior public space. Houses were built by manufacturers in the neighbourhood of the factory and established the functional and social relationship between the workplace and the residence. Caramelo Gomes and Rendeiro (2009) pointed out that they possessed a larger constructed area and the layout was either a chain configuration or isolated buildings ${ }^{25}$.

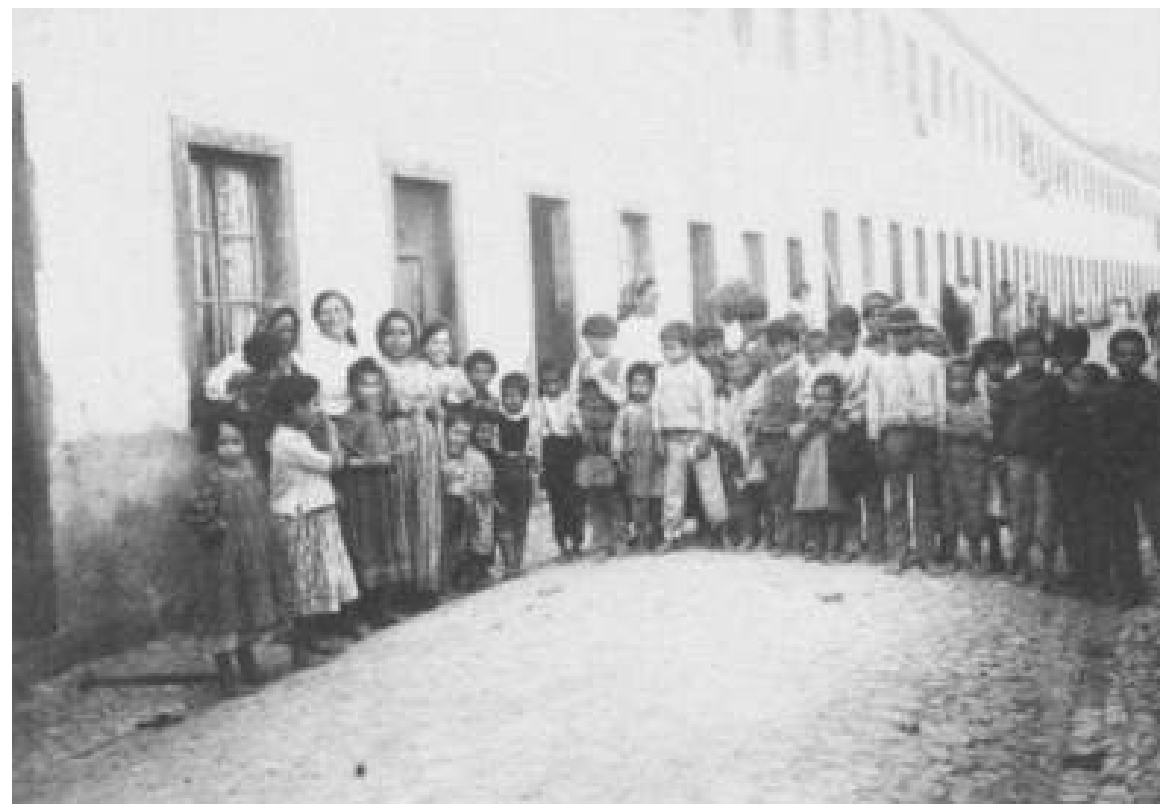

Fig. 6 - Vila Dias 190026, (Cycles Gladiator, 2008)

Built to shelter the proletariat, they showed the intention to rationalise the space available by maximizing usage. The idea of functionality, ambience and privacy was replaced by a unique and multifunctional area, equipped with a fireplace, a table and a couple of chairs. The table was used for meals, and sleeping was on and under the table. Despite the gendered pathways on villa neighborhood, (fountain and grocery for women and tavern for men) the common area stimulated communal experiences among members of the same family or just individuals that shared in the same space. Sometimes some isolation was achieved by hanging clothes as curtains. This suggested privacy visually. These 
neighborhoods only knew the technology available on manufacturing environs. The basic requirements of safety and security were not attended.

This house, with its economy of space and improved living conditions, was important and it was an innovation resulting from the "Pátios" mentioned above. Rodrigues (1978) pointed out that it was conceived as a modular shape to reach an optimum compromise between the distribution and economy space position in order to understand the city as a community 27 . The standardization of typologies, construction process and materials showed the concern to build cheaply and quickly. Neighborhood was particularly important. The community environment made this into a semi-public space, closed to the main street but integrated into the urban tissue. This type of construction was built between 1873 and 1930. It is worthy of mention that it still works in similar patterns.

This analysis showed two major aspects. On the one hand, built complexes were decorated in order to convey a social status. Their significance was ideologically fulfilled. Therefore, as Barthes (2013) suggested the myth is a purely ideological system because forms are motivated by their concepts, built complexes conveyed their arbitrary nature as semiotic signs. Their significance was decided from a range of possible alternatives that conveyed who was upper class and who was not. Furthermore, the concept of privacy was fundamental to fulfill the myth of the upper class. As far as the working class is concerned, privacy was replaced by the concept of community. This means that being social was an arbitrary concept as regards ideology and ranged from the reinvention of theatrical representation to pure and basic reinvention of community sharing.

\section{The Representation of Home in Portuguese Literature}

Os Maias by Eça de Queiroz was published in 1888. Its subtitle Episódios da Vida Romântica conveys the scope of this novel. The action is centered on an upper-class family and involves two generations. It is worthy of mention that in Os Maias, the concept of home is that of the upper class and it reflects their education, ambitions and influences.

The houses in the area of Lisbon whose description are expanded are: the Ramalhete, in Janelas Verdes, Lisbon, and A Toca, in Olivais (at that time it corresponded to the outskirts of Lisbon). These houses stand for different concepts of home, subtly summed up in their names: the home of an ancient, traditional and patriarchal family (Ramalhete) symbolized in the tile representing a bouquet placed as a coat of arms on the façade of the house; and the home of two lovers whose pursuit is that of constituting a family even before any official vows are celebrated and, thus, build their home away from the urban centre $(A$ Toca).

The typology of those houses separated the public area from the private, that is the space for convivial relationships and rituals (often associated with moments enjoyed by men or women only, such as smoking and music playing) is clearly detached from the private space (bedrooms and family intimacy) by floors ${ }^{28}$. The layout of the houses evidences the venues' mono-functionality 
suitable to activities that characterize a group of a particular social status: the dining-room for meals of the family; the living room for social intercourse; the study room for working and studying; the fumoir for smoking and talking; the billiard room for playing; the music room for playing and listening to music; the children's room with separate areas for playing and sleeping; and the kitchen, where meals were cooked only. These rooms are separated by long corridors and isolated by doors. Another aspect worthy of mention is the fact that each room located on the ground-floor, as shown in Os Maias, is separated by closed doors and curtained-off; in other words, when gentlemen are smoking, playing games and talking, they are usually isolated and, thus, the sense of belonging to a group is enhanced. Furnishings are also critical. The decision to equip each room with particular items of furniture made of particular materials, decorate it with specific curtains and carpets and the use of particular colours is indicative of the social status and upbringing. In Os Maias, the detailed description of the interior of homes also follows the strategy of clueing and showing omens of the development of the plot. The ground floor of Ramalhete is decorated with equipment that recalls Portuguese history and family tradition and wealth. The corridors are decorated with 'peças ricas de Benfica, arcas góticas, jarrões da India, e antigos quadros devotos'; the salon is decorated with paintings by Constable and the music room exhibits Gobelins tapestries; the fumoir has large ottomans; and the study room has a 'maciça mesa de pau-preto, as estantes baixas de carvalho lavrado' and a painting by Rubens. The decoration of the corridors of the first floor establishes a division between the private and the public because walls are decorated with family portraits. ${ }^{29}$

In $A$ Toca, the bedroom is of particular importance because it is the space of utmost privacy shared between the main characters. The alcove is decorated with tapestries showing Venus and Mars, velvet carpets, with a 'leito de dossel alçado sobre um estrado, coberto com uma colcha de cetim amarelo, bordada a flores de oiro, envolto em solenes cortinas também amarelas de velho brocatel'. ${ }^{30}$ Equipment and the paintings convey the family's wealth and tradition; the fact that the furniture is made of hardwood, such as oak and black wood, also suggests the family's affordability above the average and the family's resilience after years of vicissitudes and tragedies. Moreover, the textiles chosen are quality fabrics: velvet, brocade and silk: to sum up the same material used in the garments worn by the characters who dwell and visit these houses. Fashionable clothing is emphasized by accessories - hats with veils and flowers, necklaces, brooches. ${ }^{31}$ It is worthy of mention that the horse-carriages (the coupés) that carry the characters are also upholstered with velvet.

The use of colours is of particular importance in fashionable house decoration and in Os Maias, it is not an exception. Sober colours are used in public places, such as moss green, dark yellow and brown, whereas the private areas are strongly coloured: pink and red. Red suggests passion and it also suggests blood and death - as shown in the moments that precede Afonso da Maia's death. ${ }^{32}$

Environments determine clothing - horse races, concerts and formal 
dinners are convivial events and serve the purpose of cat-walking in order to seek social approval. The description of the Jockey Club offers an interesting contrast with the rest of the city on a Sunday afternoon. ${ }^{33}$ At the theatre, 'os chapéus de senhoras picados por manchas claras de plumas ou flores' are aligned with the men 'uns de gravata branca, outros de jaquetões'. ${ }^{34}$ At a formal dinner, the housewife's clothing matches the decoration of her living room.' ${ }^{35}$ Os Maias is full of social criticism: against the Portuguese narrow-minded ambitions, inappropriate manners and lack of proper education. It shows the cosmopolitanism of the Portuguese but it also conveys the extent to which they can exhibit a cosmopolitan way of living and dressing without being truly cosmopolitan. Hence, the obvious discomfort about wearing particular fashionable clothes of Parisian inspiration - at the time the world centre of fashion - and the overall result of artificiality. ${ }^{36}$

The Lisbon of the end of 19 th century was a city of deep social contrasts: on the one hand, there were neighbourhoods for the well-dressed upper classes, with reasonable accesses and improved living conditions and, on the other hand, there were neighbourhoods for the working classes. ${ }^{37}$ The literature influenced by the Realist Movement focused on urban social contrasts. Fashion and beauty were concepts associated with the comfort enjoyed by the upper classes with their clothing and housing, whereas the lower classes were ragged, ugly, and barely survived with their under-paid jobs and lived in uncomfortable houses.

In 1918, the Portuguese novelist Abel Botelho published Amanhã, the third novel of a five-volume series entitled 'Patologia Social'. 38 The geography of this novel could be studied as a representation of the living standards and aspirations of the working class population. The novel pinpoints poverty, unemployment, hunger, and disease as niches from which the working class revolutionary movement emerged. Two vilas operárias were the hubs of this movement and upon which Botelho's mapping was organized: Vila Dias, in Marvila, the eastern quarter of Lisbon, and Vila Fiúza, in Alcântara, in the western quarter of the capital. These 'vilas' are built in the narrative as two islands in the city.

The location of Vila Dias in a peripheral area of Lisbon, away from its historical and political centre, reinforced its social marginality, being populated by those who held no social status. The geographic centrality of Vila Fiúza was emphasized in the plot as an indicator of potential weakness of the working class. Yet, geographical distance and some rivalry between dwellers did not deter the fact that they were connected by the nature of their daily life and routines. As far as the description of the interior of the houses was concerned, despite it being associated with the concept of home, it was totally deprived of any connotations to comfort and fashion. It was reduced to a venue grossly organized and equipped. ${ }^{39}$ The division between the public and the private spheres was feeble due to the non-existence of corridors and doors and the use of glass (transparency), screens and curtains. The bedroom had direct access to the living areas - dining-room and kitchen. Meals were cooked and eaten in one place and the access to bedrooms was not preserved from the public eye. As far as 
furnishings were concerned, fashion gave place to affordability, shown in the use of basic soft wood furniture. There was only the basic equipment for the essential functions planned for each room: a bedroom and a wardrobe in a bedroom; a sink, chimney, chest and a set of pine table and chairs in the living areas. Materials used at home and the fabrics used for clothing were similar: cotton and calico worn over and over again. On the one hand, the separation between the public and the private was less visible when compared with the houses of the upper classes, as shown in Os Maias; on the other hand, the 'vilas operárias', as shown in Amanhã , reinvented the multi-functional features of the houses and part of their equipment before the 18 th century.

\section{Conclusion}

The myth can be historically defined and implies a relation with the interpreter; in other words, it addresses the 'you', the one who sees or reads it. Significance is achieved through convention and the novel can be defined as a formal structure. Hence, traditional literature is a characterized mythical system because speech is a meaningful signifier and the literary speech is significance. Barthes (2013) stated that literature is a myth in second degree, that is, the process of significance operates upon another semiotic system. As far as the realist literature is concerned, it is mythical by nature because it does not represent real - it signifies and conveys real.

Therefore, those novels whose housing typologies and interiors were under analysis, recreated built complexes, furnishings and equipment and signified what their authors pursued. The descriptions were based upon real houses: the mansion Silva Graça and Vila Dias. Nevertheless, the significance of Ramalhete and Vila Dias, including and very particularly, their interiors, room allocation and furnishings, were described as extensions and expansions of characters. In fact, the importance of space and its making into a place with an identity of its own - even if it complements that of its dwellers in those novels - encourages a more complex characterization of the plot and to read those novels as true 'episodes of life at the time'. In a certain sense, the built environment was part of the dwellers and complemented their fictional identity. The upper-class characters were given the privilege of owning their privacy, deciding upon the moments when to socialize and enjoy their individuality. The working-class were either secluded from socialization with the upper class or deprived of the right of fully enjoying their privacy at home.

This paper established that the physical environment has an impact on human behaviour particularly in the way it illustrates social, cultural and economic characteristics of the individual and community; furthermore it showed the importance of spatial features to create ambiences that motivates and characterises human moods. Space becomes the place whenever an individual becomes a user and interacts with others. Sir Churchill (1944) stated that "We shape our dwellings, and afterwards our dwelling shapes us" 40 . This was also true at the end of 19th century, as shown in the analysis of mansion Silva Graça and Vila Dias and in the novels published at that time. 
Interior environs, particularly those at home, were an extension of the self, where requirements and expectations fostered a non-verbal language that communicated a temporal reality featured on characters and scenarios. Space is perceived as a granted physical condition. Hall (1959) concluded "Yet we treat space somewhat as we treat sex. It is there but we don't talk about it. And if we do, we certainly are not expected to get technical or serious about it" ${ }^{41}$

Man is the measure of the house. The concept of well-being is a human requirement based upon the human cultural background. It is not possible to misunderstand the idea of comfort when decoration is a volatile reality depending on fashion throughout a short life cycle. Comfort is supported by social human behaviour, resulting from habits and performances, with a long life cycle by nature. It is important to look back and realise what is important to learn and what can still be applied. The idea of comfort is a cultural concept whose success depends on looking back to its history and be conscientious that comfort appeals to physical, intellectual and emotional human reactions in different ways periods of history. Interiors were scenarios for the pursuit of comfort and well-being. These requirements were illustrated by the development in technical environs, such as sanitation; and the functionality of spatial layouts and the ambiences, such as the dichotomy introduced by the pursuit of privacy and the carrying out of social rituals. Besides daily routines, the creation of ambiences reveals the awareness the human senses, stimulated by colours, textures, aromas, cosiness and openness; the gender typology of functionality and ambience of space despite social classes; and the public or private character of the space. Living at home is an ideological decision because the dweller decides on the furniture and on any item of equipment based on criteria that go beyond the limits of the concept of usefulness. Colours, fabrics and texture convey and signify affordability and owners aim to enjoy comfort and social status.

\section{NOTAS}

\footnotetext{
${ }^{1}$ BAKER, R. G. - Ecological psychology: Concepts and methods for studying the environment of human behavior. Stanford, Ca: Stanford University Press, 1968. ISBN 9780804706582

2 HERTZBERGER, H. - Lessons for Students in Architecture. Rotterdam: 010 Publishers, 2005. ISBN 9064505624

${ }^{3}$ BARTHES, R. - Mythologies: The Complete Edition, in a New Translation. Hill and Wang, 2013. ISBN 0374532346

${ }^{4}$ LEITE, J. - "Palacete Silva Graça". In: Restos de Colecção. Blog Discussion [online]. Lisboa: José Leite, 30 July 2012 [cited 16 Mai 2013]. Available from Internet: $<$ http://restosdecoleccao.blogspot.pt/search/label/Palacetes $>$.

${ }^{5}$ CYCLES GLADIATOR - Lisboa-de-1850-a-1974 [online]. 2008 [cited 16 October 2010]. Available from Internet: <http://jmgs.fotosblogue.com/r598/Lisboa-de-1850-a-1974/>.

${ }^{6}$ QUEIROZ, E. de, Os Maias - Episódios da Vida Romântica Lisbon: Clásicos Porto Editora, 2010, ISBN 978972-0-04957-5

${ }^{7}$ BOTELHO, A. - Amanhã - Patologia Social. Vol.III, Porto: Lello Editores, 1984, ISBN 9789724806761

${ }^{8}$ CARAMELO GOMES, C. and AOUAD, G. — “Telework, Housing and Urban Planning”. In Telework 99 Aahrus. Aahrus - Denmark: European Comission, 1999, pp. 139-155.

${ }^{9}$ The literal translation of this expression is 'there goes water!' and it refers to the wastewater or sewage thrown through windows onto streets.
} 
${ }^{10}$ CARAMELO GOMES, C. and RENDEIRO, M. - "Tomorrow or the Natural Order of Things: A Study for a Possible Gentrification of the Lisbon "Vilas Operárias"". In Proceedings of the RIPAM - Encontro Internacional sobre Património Arquitectónico do Mediterrâneo., Lisbon, October 2009.

${ }^{11}$ CYCLES GLADIATOR - Lisboa-de-1850-a-1974 [online]. 2008 [cited 16 October 2010]. Available from Internet: <http://jmgs.fotosblogue.com/r598/Lisboa-de-1850-a-1974/>.

${ }^{12}$ RYBCZYNSKI, W. - Home: A Short History of an Idea. New York: Penguin, 1987. ISBN 0140102310.

${ }^{13}$ LEITE, J. - “Armazéns do Chiado”. In: Restos de Colecção. Blog Discussion [online]. Lisboa: José Leite, 13 January 2012 [cited 16 Mai 2013]. Available from Internet: $<$ http://restosdecoleccao.blogspot.pt/search?q=armazens+do+chiado $>$.

${ }^{14}$ MUTHESIUS, S. - The Poetic Home: Designing the Nineteenth-Century Domestic Interior. London: Thames \& Hudson, 2008. ISBN 0500514194.

15 THORNTON, P. - Authentic Decor: The Domestic Interior 1620 - 1920. London: Seven Dials, 2001. ISBN 1841881090.

16 CHU, P. - Nineteenth-Century Art Worldwide [online]. 2011 [cited 16 Mai 2013]. Available at http://www.19thc-artworldwide.org/index.php/spring11/the-poetic-home-designing-19th-century-domesticinterior-stefan-muthesius\#_ftn2

${ }^{17}$ MUTHESIUS, S. - The Poetic Home: Designing the Nineteenth-Century Domestic Interior. London: Thames \& Hudson, 2008. ISBN 0500514194

${ }^{18}$ LEITE, J. - "Palacete Silva Graça”. In: Restos de Colecção. Blog Discussion [online]. Lisboa: José Leite, 30 July 2012 [cited 16 Mai 2013]. Available from Internet: $<$ http://restosdecoleccao.blogspot.pt/search/label/Palacetes $>$.

${ }^{19}$ ELEB, M. and DEBARRE, A. - Architectures de la vie privée XVIIe-XIXe siècles. Hazan, 1999. ISBN 2850256978 .

${ }^{20}$ LEITE, J. - "Palacete Silva Graça”. In: Restos de Colecção. Blog Discussion [online]. Lisboa: José Leite, 30 July 2012 [cited 16 Mai 2013]. Available from Internet: <http://restosdecoleccao.blogspot.pt/search/label/Palacetes $>$.

${ }^{21}$ LEITE, J. - "Palacete Silva Graça”. In: Restos de Colecção. Blog Discussion [online]. Lisboa: José Leite, 30 July 2012 [cited 16 Mai 2013]. Available from Internet: $<$ http://restosdecoleccao.blogspot.pt/search/label/Palacetes $>$.

22 ARIÈS, P. - Centuries of Childhood: A Social History of Family Life. New York: Vintage, 1965. ISBN 0394702867.

${ }^{23}$ SIMÃO, P.M. - Estudo de dois projectos de habitação burguesa de Norte Júnior publicados entre 1909 1911. 2009. Disponível em linha em: http://arqpapel.fa.utl.pt/pt/files/Pedro\%20Sim\%C3\%A3o.pdf.

${ }^{24}$ RYBCZYNSKI, W. - Home: A Short History of an Idea. New York: Penguin, 1987. ISBN 0140102310.

${ }^{25}$ CARAMELO GOMES, C. and RENDEIRO, M. - "Tomorrow or the Natural Order of Things: A Study for a Possible Gentrification of the Lisbon "Vilas Operárias"". In Proceedings of the RIPAM - Encontro Internacional sobre Património Arquitectónico do Mediterrâneo . Lisbon, October 2009.

${ }^{26}$ CYCLES GLADIATOR - Lisboa-de-1850-a-1974 [online]. 2008 [cited 16 October 2010]. Available from Internet: <http://jmgs.fotosblogue.com/r598/Lisboa-de-1850-a-1974/>.

27 RODRIGUES, M.J.M. - "Tradição, Transição e Mudança - A Produção do Espaço Urbano na Lisboa Oitocentista". In Boletim Cultural da Assembleia Distrital de Lisboa. 1978.

${ }^{28}$ QUEIROZ, pp.8-9; pp.431-3.

${ }^{29}$ QUEIROZ, pp.8-9.

${ }^{30}$ QUEIROZ, p.434.

${ }^{31}$ Several female characters could be chosen as examples, particularly at balls and dinners. A significant example is the first description of Maria Eduarda in QUEIROZ pp.156-7. The pet is described as an accessory which extends - through comparisons to silk and silver - the elegance, sophistication and elegance of the lady; moreover, the veil is used as an omen to what will happen as narration evolves.

${ }^{32}$ QUEIROZ, p.668. Again Uma Família Inglesa shows an interesting contrast as far as the choice of colours is concerned. The bedroom of Jenny, one of the major characters - a young, single lady - is painted in violet, conveying 'o bom gosto e a elegância desafectada, maravilhosamente unidos a um não sei quê de austeridade 
inglesa', in DINIS, J., Uma Família Inglesa, Lisbon: Clássicos Porto Editora, 2010, ISBN 978-972-0-04965-0, p. 97.

${ }^{33}$ QUEIROZ, p.313 and p.315.

${ }^{34}$ QUEIROZ, p.586.

${ }^{35}$ QUEIROZ, p.388.

${ }^{36}$ In 1890, Gervásio Lobato published Lisboa em Camisa, a satirical novel about the Lisbon society and, more specifically, about the Lisboner middle class. Artificiality and obvious mal-adjustments are also the effects of the characters dressing for a formal lunch (in, Lisbon: Vega, 1991, ISBN 9789726992783, p.43).

${ }^{37}$ It is worthy of mention the description provided by Cesário Verde in O Livro de Cesário Verde. Lisbon: Clássicos Porto Editora, 2010, ISBN 978-972-0-04978-0, pp.64-5.

${ }^{38}$ This series included the first novel Barão de Lavos (1891), the second O Livro de Alda (1898), the fourth, Fatal Dilema (1907) and the fifth, Próspero Fortuna (1910).

${ }^{39}$ BOTELHO, A., pp.10 and pp. 29-30.

40 Speech delivered in the House of Commons on October 28, 1944. http://www.drmardy.com/chiasmus/masters/churchill.shtml.

${ }^{41}$ HALL, E. T. - The Silent Language. Garden City, N.Y: Doubleday, 1959, HM 258 .H245 1973, p.163.

Fecha de recepción: 18 de junio de 2013

Fecha de revisión: 11 de julio de 2013

Fecha de aceptación: 17 de julio de 2013 